Jurnal Tanah dan Sumberdaya Lahan Vol 7 No 2 : 393-397, 2020

e-ISSN:2549-9793, doi: 10.21776/ub.jts1.2020.007.2.25

\title{
PENGARUH PEMBERIAN PUPUK ORGANIK DAN PUPUK ANORGANIK TERHADAP SERAPAN N, P, DAN K OLEH TANAMAN JAGUNG PADA ULTISOL TAMBUNAN LANGKAT
}

\section{Effect of Application of Organic and Inorganic Fertilizers on Uptake of $\mathrm{N}, \mathrm{P}$, and $\mathrm{K}$ by Maize in an Ultisol of Tambunan Langkat}

\author{
Roswita Oesman $^{1 *}$, Fitra Syawal Harahap ${ }^{2}$, Abdul Rauf ${ }^{3}$, Rahmaniah $^{1}$ \\ ${ }^{1}$ Program Studi Agroteknologi Fakultas Pertanian Universitas Pembinaan Masyarakat Indonesia \\ Sumatera Utara \\ 2 Program Studi Agroteknologi Fakultas Sains dan Teknologi Universitas Labuhanbatu Sumatera Utara \\ ${ }^{3}$ Program Studi Agroteknologi Fakultas Pertanian Universitas Sumatera Utara \\ *Penulis korespondensi : roswitaoesman@gmail.com
}

\begin{abstract}
Maize is a cereal commodity that has an important role in supporting food security and food diversification programs. The application of organic and inorganic fertilizers is one of the efforts to increase national maize productivity. This study was aimed to explore the effect of the application of organic and inorganic fertilizers on N, P and K uptake by maize in an Ultisol. Treatments tested were combinations of five levels of organic fertilizer application $(0 \%, 100 \%, 75 \%, 50 \%$, and $25 \%$ of recommended organic fertilizer dose), and five levels of inorganic fertilizer $(0 \%, 100 \%, 75 \%, 50 \%$, and $25 \%$ of recommended inorganic fertilizer dose). The twenty-five treatments were arranged in a factorial randomized block design with two replications. Results of the study showed that there was a relationship between $\mathrm{N}, \mathrm{P}$ and $\mathrm{K}$ uptake by maize with maize shoot dry weight, root weight, and shell weight. The highest plant height, shoot dry weight, and root dry weight of the maize were obtained by the treatment of $100 \%$ of organic fertilizer. The highest maize shell dry weight and uptake of N, P was obtained by the in the treatment of $75 \%$ organic fertilizer.
\end{abstract}

Keywords: inorganic fertilizer, maize, nutrient uptake, organic fertilizer, Ultisol

\section{Pendahuluan}

Ultisol merupakan jenis tanah masam dengan tingkat kesuburan rendah karena telah mengalami pelapukan intensif serta pencucian yang kuat, dengan kelarutan $\mathrm{Al}$ yang tinggi. Salah satu faktor penting dalam budidaya pertanian adalah pemupukan nitrogen $(\mathrm{N})$, fosfor $(\mathrm{P})$, dan kalium $(\mathrm{K})$ yang merupakan unsur-unsur hara makro yang berperan dalam pertumbuhan tanaman. Ketersediaan N, P, dan $\mathrm{K}$ di dalam tanah adalah faktor yang paling membatasi untuk mendapatkan pertumbuhan dan hasil maksimum dari tanaman yang dibudidayakan (Munawar, 2011). Nitrogen berperan bagi pertumbuhan vegetatif tanaman (Parsons and Sunley, 2001). Namun demikian, unsur nitrogen di dalam tanah mudah hilang disebabkan oleh pencucian, penguapan, dan digunakan oleh tanaman (Patti et al., 2018). Di sisi lain, pemberian dosis $\mathrm{N}$ berlebihan mengakibatkan pertumbuhan vegetatif berlebihan seperti pertumbuhan daun yang dapat saling menaungi sehingga proses penangkapan cahaya tidak optimal. Metabolisme lainnya yang terganggu adalah sintesis gula menjadi terhambat karena energi dipergunakan untuk sintesis $\mathrm{N}$ organik seperti yang terjadi pada tebu (Wijaya dan Soeparjono, 2014). Hal tersebut akan menganggu kemampuan akar tanaman untuk menyerap air dan unsur hara $\mathrm{N}$ dalam tanah yang pada gilirannya akan menunjang peningkatan 
perkembangan tanaman (Mengel et al., 2001). Upaya untuk meningkatan efisiensi penggunaan pupuk anorganik adalah dengan menambahkan pupuk organic ke dalam tanah karena bahan organik berperan memperbaiki sifat fisik, kimia dan biologi tanah. Peranan bahan organik dalam perbaikan sifat fisik tanah seringkali ditunjukkan melalui perbaikan struktur tanah maupun perubahan dari proporsi penyusun tekstur tanah. Sumber bahan organik yang berbeda akan mempengaruhi nilai $\mathrm{C} / \mathrm{N}$ dan komposisi bahan organik (Akbar et al., 2019). Menurut Junita et al. (2002), semakin banyak bahan organik yang diberikan pada tanah, akan diikuti dengan kenaikan kemantapan tanah mengikat air sampai batas tertentu dan kenaikan nitrogen total. Simatupang (2005) melaporkan bahwa pemberian pupuk kandang ayam dengan nyata menurunkan besarnya aliran permukaan karena pupuk kandang memperbaiki sifat fisik tanah terutama struktur sehingga permeabilitas pada tanah meningkat. Hasil penelitian Syukur dan Indah (2006) menunjukkan bahwa pemberian pupuk kandang pada tanaman jahe di tanah Inceptisol dapat meningkatkan kandungan asam humik dan asam fulvik. Asam humik dan asam fulvik ini sangat reaktif di dalam tanah karena muatan negatifnya yang sangat tinggi, sehingga dapat menyumbangkan KTK tanah.

Tujuan penelitian adalah untuk mempelajari serapan hara $\mathrm{N}, \mathrm{P}$, dan $\mathrm{K}$ oleh tanaman jagung akibat pemberian pupuk organik dan pupuk anorganik pada Ultisol Tambunan Langkat.

\section{Bahan dan Metode}

Penelitian dilaksanakan di Rumah Kaca Universitas Sumatera Utara Tambunan Langkat Serta Laboratorium Riset dan Teknologi Fakultas Pertanian Universitas Sumatera Utara Medan, pada bulan Desember 2019 sampai dengan April 2020. Bahan yang digunakan dalam penelitian ini adalah Ultisol dari Perkebunan Tambunan-A Langkat, pupuk Urea, pupuk TSP, pupuk $\mathrm{KCl}$, pupuk kandang ayam, dan benih jagung varietas Pioneer-23. Perlakuan yang diuji coba adalah kombinasi lima dosis pupuk organik (PO) dengan lima dosis pupuk anorganik (PA). Lima dosis PO tersebut adalah $\mathrm{PO}_{0}=$ tanpa pupuk organik,
$\mathrm{PO}_{1}=100 \%$ dari dosis pupuk organik, $\mathrm{PO}_{2}=$ $75 \%$ dari dosis pupuk organik, $\mathrm{PO}_{3}=50 \%$ dari dosis pupuk organik, $\mathrm{PO}_{4}=25 \%$ dari dosis pupuk organik. Dosis pupuk organic yang digunakan sesuai rekomendasi adalah $5 \mathrm{t} \mathrm{ha}^{-1}$. Lima dosis PA tersebut adalah $\mathrm{A}_{0}=$ Tanpa pupuk anorganik, $\mathrm{PA}_{1}=100 \%$ dari dosis rekomendasi pupuk anorganik, $\mathrm{PA}_{2}=75 \%$ dari dosis rekomendasi pupuk anorganik, $\mathrm{PA}_{3}=$ $50 \%$ dari dosis rekomendasi pupuk anorganik, $\mathrm{PA}_{4}=25 \%$ dari dosis rekomendasi pupuk anorganik, $\mathrm{PA}_{3}=50 \%$ dari dosis rekomendasi pupuk anorganik, $\mathrm{PA}_{4}=25 \%$ dari dosis rekomendasi pupuk anorganik. Dosis rekomendasi pupuk anorganik sesuai yang tertera pada deskripsi varietas tanaman jagung yaitu $300 \mathrm{~kg}$ Urea ha-1, $100 \mathrm{~kg}$ TSP ha-1 dan 100 $\mathrm{kg} \mathrm{KCl} \mathrm{ha-1}$. Setelah tanah dikering udarakan dan diayak dengan ayakan 10 mesh, tanah dimasukkan ke polybag setara $5 \mathrm{~kg}$ berat tanah kering oven kemudian tanah dicampur merata dengan pupuk organik dan pupuk anorganik sesuai dengan dosis masing-masing, kemudian diinkubasi selama 2 minggu. Benih jagung sebanyak 2 biji ditanam pada setiap polybag sesuai perlakuan. Penjarangan tanaman dilakukan pada umur 2 minggu setelah tanam dengan meninggalkan satu tanaman yang pertumbuhannya baik. Pada saat panen, parameter yang diukur adalah serapan N, P, dan $\mathrm{K}$ oleh tanaman jagung. Data yang diperoleh dianalisis dengan Analisis of Variance (ANOVA) untuk setiap parameter yang diukur dan diuji lanjutan bagi perlakuan yang nyata dengan menggunakan uji jarak berganda Duncan Multiple Range Test dengan taraf 5\% (Gomez dan Gomez. 1995).

\section{Hasil dan Pembahasan}

\section{Serapan $\mathbf{N}$}

Dari hasil sidik ragam dapat dilihat bahwa perlakuan pemberian pupuk organik (PO) berpengaruh nyata terhadap serapan $\mathrm{N}$ tanaman jagung. Pada perlakuan pemberian pupuk anorganik (PA) tidak berpengaruh nyata terhadap serapan $\mathrm{N}$ tanaman jagung. Kombinasi perlakuan pemberian pupuk organik dengan pupuk anorganik tidak berpengaruh nyata terhadap serapan $\mathrm{N}$ tanaman jagung (Tabel 1). Serapan $\mathrm{N}$ tanaman tertinggi adalah pemberian pupuk organik $75 \%$ 
$\left(\mathrm{PO}_{2}\right)$ yaitu $0,79 \%$ yang berbeda nyata dengan perlakuan lainnya, dan terendah pada perlakuan tanpa pupuk $\left(\mathrm{PO}_{0}\right)$. Demikian juga dengan pemberian pupuk anorganik yang tertinggi pada dosis $50 \% \quad\left(\mathrm{PA}_{3}\right)$ yaitu $0,56 \%$ dan terendah pada perlakuan tanpa pupuk $\left(\mathrm{A}_{0}\right)$. Kombinasi pupuk organik dan anorganik berpengaruh tidak nyata terhadap serapan $\mathrm{N}$ tanaman. Kombinasi tertinggi diperoleh pada pupuk organik $75 \%$ dan anorganik $50 \%$ $\left(\mathrm{PO}_{2} \mathrm{PA}_{3}\right)$. Serapan $\mathrm{N}$ tanaman terendah terdapat pada PO0A0. Peranan hara N dalam memacu pertumbuhan vegetatif dan sintesa asam amino Keefektifan dan keefisienan pemberian pupuk organik dan anorganik dapat dilihat pada pemberian $75 \%$ pupuk organik dan $50 \%$ pupuk anorganik (PO2PA3). Nitrogen berperan bagi pertumbuhan vegetatif tanaman (Parsons dan Sunley, 2001) Sehingga Peranan hara $\mathrm{N}$ dalam memacu pertumbuhan vegetatif dan sintesa asam amino, dan kemudian Kalium berfungsi antara lain pada perkembangan akar, pembentukan karbohidrat (pati), dan mempengaruhi penyerapan unsur lain. Selanjutnya fosfat berperan penting dalam pembelahan sel, perkembangan akar, pembentukan bunga dan biji, penyusun RNA dan DNA dan menyimpan, memindahkan energi (ATP dan ADP) (Marschner et al., 1986). Metabolisme lainnya yang terganggu adalah sintesis gula menjadi terhambat karena energi dipergunakan untuk sintesis $\mathrm{N}$ organik seperti yang terjadi pada tebu (Wijaya dan Soeparjono 2014).

Tabel 1. Serapan $\mathrm{N}$ oleh tanaman jagung (\%) pada perlakuan pemberian pupuk organik dan pupuk anorganik.

\begin{tabular}{lcccccc}
\hline Perlakuan & \multicolumn{6}{c}{ Pupuk Anorganik } \\
\cline { 2 - 7 } & $\begin{array}{c}\text { A0 } \\
\text { (tanpa pupuk) }\end{array}$ & $\begin{array}{c}\text { PA1 } \\
\mathbf{( 1 0 0 \% )}\end{array}$ & $\begin{array}{c}\text { PA2 } \\
\mathbf{( 7 5 \% )}\end{array}$ & $\begin{array}{c}\text { PA3 } \\
\mathbf{( 5 0 \% )}\end{array}$ & $\begin{array}{c}\text { PA4 } \\
\mathbf{( 2 5} \%)\end{array}$ & Rataan \\
\hline Pupuk Organik & & & & & & \\
PO0 (tanpa pupuk) & 0,19 & 0,51 & 0,32 & 0,36 & 0,32 & $0,33 \mathrm{~b}$ \\
PO1 (100\%) & 0,44 & 0,30 & 0,42 & 0,41 & 0,33 & $0,38 \mathrm{~b}$ \\
PO2 (75\%) & 0,20 & 0,95 & 0,93 & 1,21 & 0,63 & $0,79 \mathrm{a}$ \\
PO3 (50\%) & 0,44 & 0,47 & 0,63 & 0,20 & 0,25 & $0,40 \mathrm{~b}$ \\
PO4 (25\%) & 0,33 & 0,47 & 0,47 & 0,68 & 0,54 & $0,50 \mathrm{~b}$ \\
\hline Rataan & $\mathbf{0 , 3 3}$ & $\mathbf{0 , 5 5}$ & $\mathbf{0 , 5 5}$ & $\mathbf{0 , 5 6}$ & $\mathbf{0 , 4 1}$ & \\
\hline
\end{tabular}

Keterangan : Angka-angka yang diikuti huruf yang sama pada baris atau kolom yang sama tidak berbeda nyata pada taraf uji Duncan 5\%.

\section{Serapan $P$}

Hasil sidik ragam menunjukkan bahwa perlakuan pemberian pupuk organik (O) berpengaruh sangat nyata terhadap serapan $\mathrm{P}$ tanaman jagung. Pada perlakuan pemberian pupuk anorganik (A) tidak berpengaruh nyata terhadap serapan $\mathrm{P}$ tanaman jagung. Kombinasi perlakuan pemberian pupuk organik dengan pupuk anorganik tidak berpengaruh nyata terhadap serapan $\mathrm{P}$ tanaman jagung. Serapan $P$ tanaman jagung pada perlakuan pemberian pupuk organik dan pupuk anorganik terdapat pada Tabel 2. Serapan P tanaman tertinggi adalah pemberian pupuk organik $75 \%$ (PO2) yaitu $0,54 \%$, tidak berbeda nyata dengan $50 \%$ (PO3), dan terendah perlakuan tanpa pupuk (PO0). Demikian juga dengan pemberian pupuk anorganik yang tertinggi pada dosis 100\% (PA1) yaitu 0,53\% dan terendah pada perlakuan tanpa pupuk (A0). Kombinasi pupuk organik dan anorganik berpengaruh tidak nyata terhadap serapan $\mathrm{P}$ tanaman. Kombinasi tertinggi diperoleh pada pupuk organik $75 \%$ dan anorganik $100 \%$ (PO2PA1). Serapan P tanaman terendah terdapat pada PO0A0. Dari Tabel 2 dapat dilihat bahwa serapan $\mathrm{P}$ tanaman tertinggi adalah pemberian pupuk organik 75\% (PO2) yaitu $0,54 \%$, tidak berbeda nyata dengan $50 \%$ (PO3), dan terendah perlakuan tanpa pupuk (PO0). Demikian juga dengan pemberian pupuk anorganik yang tertinggi pada dosis 
100\% (PA1) yaitu $0,53 \%$ dan terendah pada perlakuan tanpa pupuk (A0). Kombinasi pupuk organik dan anorganik berpengaruh tidak nyata terhadap serapan $\mathrm{P}$ tanaman. Kombinasi tertinggi diperoleh pada pupuk organik 75\% dan anorganik 100\% (PO2PA1). Serapan P tanaman terendah terdapat pada PO0A0. Kondisi ini menunjukkan bahwa bahan organik pupuk organik $75 \%$ mampu menciptakan kondisi media tumbuh yang lebih baik, diantaranya mensuplai ketersediaan $\mathrm{N}, \mathrm{P}, \mathrm{K}$ Selain itu juga, bahan organik menghasilkan asam-asam organik yang berperan dalam pertukaran ligan maupun mengkelat logam sehingga P menjadi tersedia dalam tanah (Tan, 2011). Fosfor berperan bagi pertumbuhan dan perkembangan akar tanaman. Hal tersebut akan memengaruhi proses penyerapan air dan hara tanaman yang berdampak pada pertumbuhan tanaman. Selanjutnya P berperan penting dalam pembelahan sel, perkembangan akar, pembentukan bunga dan biji, penyusunan RNA dan DNA dan menyimpan, memindahkan energi (ATP dan ADP) (Marschner et al., 1986; Leiwakabesy et al., 2003).

Tabel 2. Serapan $\mathrm{P}$ oleh tanaman jagung (\%) pada perlakuan pemberian pupuk organik dan pupuk anorganik.

\begin{tabular}{lcccccc}
\hline Perlakuan & \multicolumn{7}{c}{ Pupuk Anorganik } \\
\cline { 2 - 7 } & $\begin{array}{c}\text { A0 } \\
\text { (tanpa pupuk) }\end{array}$ & $\begin{array}{c}\text { PA1 } \\
\mathbf{( 1 0 0 \% )}\end{array}$ & $\begin{array}{c}\text { PA2 } \\
\mathbf{( 7 5 \% )}\end{array}$ & $\begin{array}{c}\text { PA3 } \\
\mathbf{( 5 0 \% )}\end{array}$ & $\begin{array}{c}\text { PA4 } \\
\mathbf{( 2 5} \%)\end{array}$ & Rataan \\
\hline Pupuk Organik & & & & & & \\
PO0 (tanpa pupuk) & 0,12 & 0,29 & 0,23 & 0,31 & 0,28 & $0,24 \mathrm{c}$ \\
PO1 (100\%) & 0,39 & 0,48 & 0,38 & 0,51 & 0,47 & $0,45 \mathrm{~b}$ \\
PO2 (75\%) & 0,33 & 0,72 & 0,47 & 0,72 & 0,49 & $0,54 \mathrm{a}$ \\
PO3 (50\%) & 0,39 & 0,68 & 0,60 & 0,38 & 0,34 & $0,48 \mathrm{ab}$ \\
PO4 (25\%) & 0,36 & 0,48 & 0,50 & 0,39 & 0,31 & $0,41 \mathrm{~b}$ \\
\hline Rataan & $\mathbf{0 , 3 2}$ & $\mathbf{0 , 5 3}$ & $\mathbf{0 , 4 3}$ & $\mathbf{0 , 4 6}$ & $\mathbf{0 , 3 8}$ & \\
\hline
\end{tabular}

Keterangan : Angka-angka yang diikuti huruf yang sama pada baris atau kolom yang sama tidak berbeda nyata pada taraf uji Duncan $5 \%$.

\section{Serapan $K$}

Hasil sidik ragam menunjukkan bahwa pemberian pupuk organik $(\mathrm{O})$ maupun pupuk anorganik (A) tidak berpengaruh nyata terhadap serapan $\mathrm{K}$ tanaman jagung. Kombinasi pemberian pupuk organik dengan pupuk anorganik juga tidak berpengaruh nyata terhadap serapan $\mathrm{K}$ tanaman jagung, seperti yang disajikan padsa Tabel 3. Serapan K tanaman tertinggi adalah pemberian pupuk organik $100 \%$ (PO1) yaitu $0,24 \%$, dan terendah perlakuan 50\% (PO3). Demikian juga dengan pemberian pupuk anorganik yang tertinggi pada dosis 100\% (PA1) yaitu 0,24 \% dan terendah pada perlakuan tanpa pupuk (A0). Kombinasi pupuk organik dan anorganik berpengaruh tidak nyata terhadap serapan $\mathrm{P}$ tanaman. Kombinasi tertinggi diperoleh pada pupuk organik $100 \%$ dan anorganik 50\% (PO1PA3). Serapan K tanaman terendah terdapat pada PO0A0. Hasil ini didukung oleh serapan $\mathrm{N}$ tertinggi pada perlakuan PO2PA3 dan terandah PO0A0, serapan P tertinggi pada perlakuan PO2PA1 dan terandah perlakuan PO0A0, dan serapan $K$ tertinggi pada perlakuan PO1PA3 dan terandah perlakuan PO0A0. kemudian K berfungsi antara lain pada perkembangan akar, pembentukan karbohidrat dan mempengaruhi penyerapan unsur lain (Agustina et al., 2010).

\section{Kesimpulan}

Pemberian pupuk organik $75 \%$ dari dosis rekomendasi pupuk anorganik menunjukan dapat meningkatkan serapan hara N, P dan oleh tanaman pada Ultisol. Pemberian pupuk anorganik 25\% dari dosis rekomendasi pupuk anorganik meningkatkan serapan hara N, P dan K oleh tanamnan jagung pada Ultisol. 
Jurnal Tanah dan Sumberdaya Lahan Vol 7 No 2 : 393-397, 2020

e-ISSN:2549-9793, doi: 10.21776/ub.jts1.2020.007.2.25

Tabel 3. Serapan K oleh tanaman jagung (\%) pada perlakuan pemberian pupuk organik dan pupuk anorganik.

\begin{tabular}{lcccccc}
\hline Perlakuan & \multicolumn{7}{c}{ Pupuk Anorganik } \\
\cline { 2 - 7 } & $\begin{array}{c}\text { A0 } \\
\text { (tanpa pupuk) }\end{array}$ & $\begin{array}{c}\text { PA1 } \\
\mathbf{( 1 0 0 \% )}\end{array}$ & $\begin{array}{c}\text { PA2 } \\
\mathbf{( 7 5 \% )}\end{array}$ & $\begin{array}{c}\text { PA3 } \\
\mathbf{( 5 0 \% )}\end{array}$ & $\begin{array}{c}\text { PA4 } \\
\mathbf{( 2 5 \% )}\end{array}$ & Rataan \\
\hline Pupuk Organik & & & & & & \\
PO0 (tanpa pupuk) & 0,08 & 0,22 & 0,17 & 0,16 & 0,23 & 0,17 \\
PO1 (100\%) & 0,13 & 0,22 & 0,23 & 0,36 & 0,27 & 0,24 \\
PO2 (75\%) & 0,13 & 0,35 & 0,16 & 0,34 & 0,23 & 0,24 \\
PO3 (50\%) & 0,15 & 0,19 & 0,13 & 0,18 & 0,13 & 0,16 \\
PO4 (25\%) & 0,16 & 0,21 & 0,19 & 0,16 & 0,15 & 0,17 \\
\hline Rataan & $\mathbf{0 , 1 3}$ & $\mathbf{0 , 2 4}$ & $\mathbf{0 , 1 8}$ & $\mathbf{0 , 2 4}$ & $\mathbf{0 , 2 0}$ & \\
\hline
\end{tabular}

Keterangan : Angka-angka yang diikuti huruf yang sama pada baris atau kolom yang sama tidak berbeda nyata pada taraf uji Duncan 5\%.

\section{Daftar Pustaka}

Agustina, K., Sopandie, D., Trikoesoemaningtyas, dan Wirnas, D. 2010. Tanggap fisiologi akar sorgum (Sorghum bicolor L. Moench) terhadap cekaman alumunium dan defisiensi fosfor di dalam rhizotron. Jurnal Agronomi Indonesia 38(2): 88-94.

Akbar, A.N., Azizah, N. dan Suminarti, N.E. 2019. Pengaruh sumber dan dosis bahan organik pada pertumbuhan dan hasil tanaman jagung (Zea mays) di lahan sawah. Jurnal Produksi Tanaman 7(2): 225-233.

Gomez, K.A. and Gomez, A.A. 1995. Statistical procedures for agricultural research (Prosedur statistik untuk penelitian pertanian, alih bahasa E. Syamsuddin, JS Baharsyah, dan $\mathrm{AH}$ Nasution).

Junita, F., Muhartini, S. dan Kastono, D. 2002. Pengaruh frekuensi penyiraman dan takaran pupuk kandang terhadap pertumbuhan dan hasil pakchoi. Jurnal Ilmu Pertanian 9(1):37-45.

Marschner, H., Römheld, V. and Kissel, M. 1986. Different strategies in higher plants in mobilization and uptake of iron. Journal of Plant Nutrition 9(3-7): 695-713.

Mengel, K., Kirkby, E.A., Kosegarten, H. and Appel, T. 2001. Principles of Plant Nutrition. 5th Ed., Kluwer Academic Publ., London.
Munawar, A. 2011. Kesuburan Tanah dan Nutrisi Tanaman. Bogor (ID): IPB Press.

Parsons, R. and Sunley, R.J. 2001. Nitrogen nutrition and the role of root-shoot nitrogen signalling particularly in symbiotic System. Journal of Experimental Botany 52(1): 435-443.

Patti, P.S., Kaya, E. dan Silahooy, C. 2018. Analisis status nitrogen tanah dalam kaitannya dengan serapan $\mathrm{N}$ oleh tanaman padi sawah di Desa Waimital, Kecamatan Kairatu, Kabupaten Seram Bagian Barat. Agrologia: Jurnal Ilmu Budidaya Tanaman 2(1): 51-58.

Simatupang, P. 2005. Pengaruh pupuk kandang dan penutup tanah terhadap erosi pada tanah Ultisol Kebun Tambunan DAS Wampu, Langkat. Jurnal Ilmiah Pertanian Kultura 40(3): 89-92.

Syukur, A. dan Indah, M.N. 2006. Kajian pengaruh pemberian macam pupuk organik terhadap pertumbuhan dan hasil tanaman jahe di Inceptisol, Karanganyar. Jurnal Ilmu Tanah Lingkungan 6(2): $124-131$.

Tan, K.H. 2011. Principles of soil chemistry. CRC Press.

Wijaya, K.A. dan Soeparjono, S. 2014. Efek suplai nitrogen terhadap kadar gula nira tebu varietas Bululawang. Jurnal Agritrop 12(2): 109-112. 
halaman ini sengaja dikosongkan 